Volume 7, Issue 4, 805 - 812.

ISSN: 2165-8714

http://www.eu-jer.com/

\title{
Socio-Scientific Issues as a Context for STEM Education: A Case Study Research with Pre-Service Science Teachers *
}

\author{
Esra Bozkurt Altan ** \\ Sinop University, TURKEY
}

\author{
Nurhan Ozturk \\ Sinop University, TURKEY
}

\author{
Ayse Yenilmez Turkoglu \\ Alanya Alaaddin Keykubat University, \\ TURKEY
}

Received: June 18, 2018 • Revised: August 21, $2018 \cdot$ Accepted: September 17, 2018

\begin{abstract}
This study was designed as a case study. Participants were 12 senior pre-service science teachers (PSTs), who took theoretical and practical courses about STEM education and socio-scientific issues (SSIs) during their education at a state university. For the study, in the first 4 weeks, theoretical courses on SSIs and STEM education were carried out. Afterwards, PSTs were asked to choose a SSI and configure this issue as a problem statement to perform a STEM activity. Participants were given a total of 3 weeks to determine the issue and prepare the STEM activity, and the researchers of the study gave systematic feedback during this period. Then, starting from the fifth week of the study, groups started to implement their STEM activities in the class, where their peers were assigned as their students. The activity plans they prepare, the field notes taken by the researchers during the implementation of the activities and the semi-structured interviews about the opinions of the PSTs on the use of SSI in STEM education were the data sources of the study. Findings revealed that PSTs found establishing STEM problem situations over SSIs suitable since they provide features such as conformity to real life, having multiple criteria and providing compatibility with other disciplines. Moreover, after their practices, they pointed out that the activities enabled both the teaching of the SSI and the integrated teaching to be carried out. As a conclusion, it is recommended to use socio-scientific problem situations to perform STEM education.
\end{abstract}

Keywords: STEM education, socio-scientific issues, pre-service science teachers.

To cite this article: Bozkurt Altan, E., Ozturk, N. \& Yenilmez Turkoglu, A. (2018). Socio-scientific issues as a context for stem education: A case study research with pre-service science teachers. European Journal of Educational Research, 7(4), 805-812. doi: 10.12973/eu-jer.7.4.805

\section{Introduction}

In STEM education, learners face with problem situations that are related to their past experiences and are compatible with the social and cultural environment they live in and with the work of professionals in real life, and that have at least two components of STEM disciplines and have multiple solutions; and a holistic and meaningful learning is expected as they probe solutions to the problems (Bozkurt Altan, 2017). By this way, it is aimed to contribute to the development of career awareness, interest in STEM field, and the development of the 21st Century Skills. Researchers claim that STEM education contributes to the development of the 21st century skills. Critical thinking and reasoning, creative and innovative thinking, decision-making, communication and collaboration skills, leadership and entrepreneurship, and information literacy can be expressed as a few of these skills (International Society for Technology in Education [ISTE], 2007; Partnership for 21st Century Skills [P21], 2013).

In the related literature, the importance of establishing an appropriate problem situation that will start the learning process in STEM education is frequently emphasized (Breiner, Harkness, Johnson \& Koehler, 2012; Bybee, 2010; Chiu, Price \& Ovrahim, 2015; Harrel, 2010; NAE [National Academy of Engineering] \& NRC [National Research Council], 2009; NRC, 2012; Sanders, 2009). In most studies, engineering-design problems are taken to be an appropriate context for STEM education. In these approaches, which are structured around an engineering problem and use the engineering design process, engineering problems represent an important context to combine the disciplines of science, technology and mathematics (Hmelo, Holton \& Kolodner, 2000; Mehalik, Doppelt \& Schunn, 2008; Moore, Stohlmann, Wang, Tank \& Roehrig, 2014; Sadler, Coyle \& Schwartz, 2000). In addition, practices structured on the problem situations that are harmonious with the social-cultural environment that students live in and that can be solved through interdisciplinary collaboration, are represented as appropriate problem situations for STEM education, as well (Asghar, Ellington, Rice,

* A part of this study was presented in II. International Academic Research Congress (INES-2017).

** Corresponding author:

Esra Bozkurt Altan, Sinop University, Science and Mathematics Education Department, Turkey.

Email: esrabozkurt@sinop.edu.tr 
Johnson \& Prime, 2012; Chen, 2007; Lou, Shih, Diez \& Tseng, 2011; Tsai, 2007). This study is based on the use of socioscientific issues (SSIs) as appropriate problem situation contexts that overlap with the objectives of STEM education.

SSIs are complex, open-ended, mostly controversial, and socially important daily life scientific issues without definite answers (Topcu, 2010). They are meaningful and important in social life (Eastwood et al., 2012). Examples of SSIs include renewable energy sources, nuclear energy, genetically modified organisms (GMOs) and global warming, which are closely concerning the societies in the century we are living in (Fleming, 1986; Zeidler, Walker, Ackett \& Simmons, 2002). In this sense, by giving place to SSIs in science education, it is frequently aimed to improve students' ability to make decisions, analyze, synthesize and evaluate (Zeidler, 2001). Nevertheless, many science educators, who emphasized the importance of teaching SSIs, pointed out that these issues should be included in science classes (Driver, Newton \& Osborne, 2000; Kolstø, 2001; Zeidler, 1984).

SSIs, concerning all the individuals in a society, can be considered as important contexts for STEM education as they are interdisciplinary in structure (including STEM disciplines) and as they include science content knowledge and comply with real life experiences in terms of socio-cultural content. While students are attempting to make decisions by reasoning about the SSIs that are structured as problem situations, they employ the embedded STEM disciplines in these problems. Khan (2015) responds to the frequently asked questions about engineering design problem like "what are the needs or expectations?", "what can we make compromises from?" as SSIs allow for debate and reasoning and thus overlap with the aims of STEM education. Problems handled in the context of SSIs and STEM education reflect the real life. The involvement of SSIs in STEM education contributes not only to the awareness of the existence of different disciplines within the SSIs but also raise individuals' awareness about social issues (Zouda, Halwany, Milanovic \& Bencze, 2017). Similarly, drawing attention to the fact that STEM education should be handled within the framework of the SSIs and reasoning, Zeidler (2016) points out that STEM researchers should consider these issues. As researchers noted, discussing SSIs on the axis of STEM education, and planning, implementing and evaluating some instructional practices may provide important findings for the use of SSIs to achieve STEM education, the latest of interdisciplinary learning approaches. Indeed, when the studies addressing the characteristics of SSIs (Eastwood, Sadler, Zeidler, Lewis, Amiri, \& Applebaum, 2012; Fleming, 1986; Topcu, 2010; Zeidler, Walker, Ackett \& Simmons, 2002; Zeidler, 2001) and the nature of the STEM education (Asghar, et al. 2007; Breiner, et al. 2007; Bybee, 2010; Moore, et al. 2014) are addressed, it seems worthwhile to investigate the use of SSIs as appropriate contexts for STEM education.

\section{Methodology}

\section{Aim of the Study}

In this study, it was aimed to determine pre-service science teachers' (PSTs') evaluations of the use of SSIs in STEM education.

\section{Participants and Data Collection}

Based on the qualitative research paradigm, this study is designed as a case study. Marshall and Rossman (2006) note that case studies are used in the evaluation of a program or in an in-depth and detailed description of a phenomenon. Yin (2009) examines case studies under four patterns in respect to the case and its units of analysis. In this study, PSTs' evaluations of the use of SSIs in STEM education were taken as a whole. Therefore, the research was planned as a holistic single case study.

Participants were 12 senior PSTs at a state university and were selected purposefully. They were purposefully selected because the aim of the study requires a study group who had theoretical and practical experiences on STEM education and SSIs. During their education, the PSTs took several science courses (physics, chemistry, biology and mathematics) together with the courses that meet the content and objectives of the science curriculum. The PSTs took an elective course with a total of 28 hours on SSIs and their instruction, and two other courses with a total of 84 hours on theoretical and practical STEM education.

The research was carried out in an elective course. During the first 4 weeks of the 14 -week period, theoretical lectures on SSIs and STEM education were given. During the theoretical lectures, presentations about STEM and SSIs were done for the purpose of revisiting these issues that the PSTs were already informed about. In relation to the SSIs, topics like (i) what makes a topic socio-scientific? (ii) SSIs and daily life, and (iii) sample practices related to the SSIs, were addressed. In terms of STEM, on the other hand, (i) STEM disciplines and future, (ii) the importance of STEM education, and (iii) examination of STEM activities, were covered. Finally, SSIs as a context for STEM education were discussed. The PSTs were then asked to choose a socio-scientific issue and configure this issue as a problem statement to perform a STEM activity. They worked in groups of 2-3 people and a total of 5 groups were formed. The PSTs worked in groups during the practice. The groups were given a total of 3 weeks to determine the issue and prepare the STEM activity, and the researchers of the study gave systematic feedback during this period. STEM education starts with a problem statement. The problem should be appropriate for the environment that the students are living in, should bear multiple solutions, should be related to the past experiences, and should provide a problematic situation where at least one of the disciplines of technology, engineering and mathematics can be integrated. Finally, the activities should be conducted as group works. In this direction, the PSTs were asked to structure the problem situation on a SSI. Starting 
from the fifth week of the study, groups started to implement their STEM activities in the class, where their peers were assigned as their students. After the activities, PSTs' evaluations of the activities were taken. The question "How do you evaluate the activity? Explain in detail." was directed to the PSTs and each PST evaluated the process in written form. In addition, researchers of the study observed all activities and took field notes. After all of the activities were carried out, PSTs' opinions about the use of SSIs in STEM education were taken. Face-to-face interviews were held with each PST and detailed views were provided on the use of SSIs in STEM education. Thereby, interviews with PSTs, field notes of researchers and activity plans prepared by PSTs constituted the data sources of this study.

\section{Data Analysis}

The field notes taken by the researchers and the opinions of the pre-service teachers were analyzed through content analysis, while descriptive analysis and constant comparative method (Strauss \& Corbin, 1994) were conducted in the analysis of the activity plans. The coding scheme, developed by Ercan (2015), based on the work of other researches (Bowers, 2015; Stearns, Morgan, Capraro, \& Capraro, 2012; Stohlmann, Moore, \& Roehrig, 2012), was used as a descriptive partial analysis framework for the evaluation of STEM lesson plans (See Table 1). The coding scheme consists of the dimensions of content, approach, measurement and evaluation. While the lesson plans were analyzed based on the coding scheme suggested by Ercan (2016), two more codes related to the problem situation were added to the content category in the analysis process, which is in line with the nature of the continuous comparative analysis technique. A sample coding scheme used in the analysis of the content dimension of lesson plans is presented in Table 1.

Table 1. Coding scheme of content dimension

\begin{tabular}{|c|c|c|c|}
\hline Category & Codes & & Explanations \\
\hline \multirow{9}{*}{ Content } & Integration & Only science (only_sci) & Only science learning goals are taken into account. \\
\hline & & $\begin{array}{l}\text { Science ad another } \\
\text { independent discipline } \\
\text { (sci\&ind }=1 \text { ) }\end{array}$ & $\begin{array}{l}\text { In addition to science, learning goals are taken into } \\
\text { account for another STEM discipline, but } \\
\text { interdisciplinary links are not mentioned, disciplines } \\
\text { are addressed separately. }\end{array}$ \\
\hline & & $\begin{array}{l}\text { Another discipline integrated } \\
\text { with science }(\text { sci\&dep=1) }\end{array}$ & $\begin{array}{l}\text { In addition to science, learning goals are taken into } \\
\text { account for another STEM discipline and links } \\
\text { between knowledge and practices of disciplines are } \\
\text { mentioned. }\end{array}$ \\
\hline & & $\begin{array}{l}\text { Science and other } \\
\text { independent disciplines } \\
(\text { sci\&ind }>1)\end{array}$ & $\begin{array}{l}\text { In addition to science, learning goals are taken into } \\
\text { account for other STEM disciplines, but } \\
\text { interdisciplinary links are not mentioned, disciplines } \\
\text { are addressed separately. }\end{array}$ \\
\hline & & $\begin{array}{l}\text { Other disciplines integrated } \\
\text { with science }(\text { sci\&dep }>1)\end{array}$ & $\begin{array}{l}\text { In addition to science, learning goals are taken into } \\
\text { account for other STEM disciplines and links between } \\
\text { knowledge and practices of disciplines are } \\
\text { mentioned. }\end{array}$ \\
\hline & \multirow[t]{2}{*}{$\begin{array}{l}\text { Solutions } \\
\text { to the } \\
\text { problem }\end{array}$} & $\begin{array}{l}\text { Problem situation involving } \\
\text { multiple solutions }\end{array}$ & $\begin{array}{l}\text { Problem situation includes multiple solutions to } \\
\text { reflect the multi-criteria decision-making process. }\end{array}$ \\
\hline & & $\begin{array}{l}\text { Problem situation involving a } \\
\text { single solution }\end{array}$ & The problem involves only a correct solution. \\
\hline & \multirow{2}{*}{$\begin{array}{l}\text { Daily life } \\
\text { context of } \\
\text { the } \\
\text { problem }\end{array}$} & $\begin{array}{l}\text { Problem is appropriate to } \\
\text { daily life. }\end{array}$ & $\begin{array}{l}\text { Problem is compatible with the life context of the } \\
\text { target. }\end{array}$ \\
\hline & & $\begin{array}{l}\text { Problem is not appropriate to } \\
\text { daily life. }\end{array}$ & $\begin{array}{l}\text { Problem is not compatible with the life context of the } \\
\text { target. }\end{array}$ \\
\hline
\end{tabular}

The activity plans of each group were evaluated separately by two different researchers according to the partial framework. Reliability was calculated with the help of the formula proposed by Miles and Huberman (1994): (Reliability $=$ [Total Number of Agreements $\div$ (Total Number of Agreements + Disagreements)] x 100) and 96\% consistency was found among the researchers. 


\section{Findings}

Findings related to the activity plans are given in Table 2.

Table 2. Findings related to the appropriateness of SSI and STEM integrated activity plans to STEM education

\begin{tabular}{|c|c|c|c|c|c|}
\hline Category & $\begin{array}{l}1^{\text {st }} \text { Group } \\
\text { Fuel Type }\end{array}$ & $\begin{array}{l}2^{\text {nd }} \text { Group } \\
\text { Cloning }\end{array}$ & $\begin{array}{l}3^{\text {rd }} \text { Group } \\
\text { GMOs }\end{array}$ & $\begin{array}{l}4^{\text {th }} \text { Group } \\
\text { Nuclear } \\
\text { Power }\end{array}$ & $\begin{array}{l}5^{\text {th }} \text { Group } \\
\text { Hydroelectric } \\
\text { Power }\end{array}$ \\
\hline \multirow[t]{3}{*}{ Content } & $\begin{array}{l}\text { Science } \\
\text { integrated with } \\
\text { mathematics }\end{array}$ & $\begin{array}{l}\text { Science } \\
\text { integrated with } \\
\text { mathematics }\end{array}$ & $\begin{array}{l}\text { Science } \\
\text { integrated with } \\
\text { mathematics } \\
\text { and } \\
\text { engineering }\end{array}$ & $\begin{array}{l}\text { Science } \\
\text { integrated with } \\
\text { mathematics } \\
\text { and } \\
\text { engineering }\end{array}$ & $\begin{array}{l}\text { Science } \\
\text { integrated with } \\
\text { mathematics }\end{array}$ \\
\hline & $\begin{array}{l}\text { Problem with } \\
\text { more than one } \\
\text { solution }\end{array}$ & $\begin{array}{l}\text { Problem with } \\
\text { more than one } \\
\text { solution }\end{array}$ & $\begin{array}{l}\text { Problem with } \\
\text { more than one } \\
\text { solution }\end{array}$ & $\begin{array}{l}\text { Problem with } \\
\text { more than one } \\
\text { solution }\end{array}$ & $\begin{array}{l}\text { Problem with } \\
\text { more than one } \\
\text { solution }\end{array}$ \\
\hline & $\begin{array}{l}\text { Real-life } \\
\text { context is } \\
\text { appropriate }\end{array}$ & $\begin{array}{l}\text { Real-life } \\
\text { context is } \\
\text { appropriate }\end{array}$ & $\begin{array}{l}\text { Real-life } \\
\text { context is } \\
\text { appropriate }\end{array}$ & $\begin{array}{l}\text { Real-life } \\
\text { context is } \\
\text { appropriate }\end{array}$ & $\begin{array}{l}\text { Real-life } \\
\text { context is } \\
\text { appropriate }\end{array}$ \\
\hline Approach & $\begin{array}{l}\text { Planned with } \\
\text { problem based } \\
\text { learning }\end{array}$ & $\begin{array}{l}\text { Planned with } \\
\text { problem based } \\
\text { learning }\end{array}$ & $\begin{array}{l}\text { Planned with } \\
\text { problem based } \\
\text { learning }\end{array}$ & $\begin{array}{l}\text { Planned with } \\
\text { problem based } \\
\text { learning }\end{array}$ & $\begin{array}{l}\text { Planned with } \\
\text { problem based } \\
\text { learning }\end{array}$ \\
\hline $\begin{array}{l}\text { Measurement } \\
\text { and Evaluation }\end{array}$ & $\begin{array}{l}\text { Planned } \\
\text { integrated }\end{array}$ & $\begin{array}{l}\text { Planned } \\
\text { integrated }\end{array}$ & $\begin{array}{l}\text { Planned } \\
\text { integrated }\end{array}$ & $\begin{array}{l}\text { Planned } \\
\text { integrated }\end{array}$ & $\begin{array}{l}\text { Planned } \\
\text { integrated }\end{array}$ \\
\hline
\end{tabular}

As can be seen in Table 2, in the STEM activity plans that they prepared based on socio-scientific problem situations, PSTs integrated science content with other disciplines. Moreover, it was also observed that the problems had more than one solution and their contexts were appropriate to real life. PSTs planned socio-scientific problem situations for STEM education in the context of problem based learning practices. In addition, measurement and evaluation were planned in all activity plans, and they included an integration of the content disciplines, rather than a single discipline.

One of the problem situations prepared by the PSTs is as follows:

"Before entering the sectarian wars, Syria itself had economies that could respond to their needs and the needs of the people in the economic direction. Because of the war that took place in 2008, the country has suffered from depreciation in every aspect of life, and many people - young or old - either left their homes or became martyrs. Syria, trying to get over the odds of war, is looking for ways to get back to old welfare and happy days. Therefore, in the meeting with the ministers, Syrian President Dilbirin expressed his desire about the happiness and welfare of Syria again. He expressed the necessity of using GMOs to the ministers." (PST4)

"You are a member of an expert group of officials in the Ministry of Food and Agriculture and the Ministry of Health. You are asked to do a detailed work on this subject and decide on GMOs." (PST6)

In the activity that starts with the problem statement above, a scaled drawing of the landscape is presented and students are expected to make an agricultural design for this place by selecting appropriate seeds and plants. Questions like "what are GMOs?" "Are they useful or harmful?" are asked. Examination of the tables/graphs on the comparison of the production costs and productivity of GMO products and non GMO products and the development of mathematical models; investigation of short- and long-term damages of GMO products to human health and ecosystem; and investigation of alternative solutions for the cultivation of agricultural fields were performed.

PSTs' opinions about creating problem situations for STEM activities through SSIs were examined and all PSTs (f = 12) indicated that SSIs provide a suitable basis for the development of problem situations for STEM education. In addition, PSTs pointed out that, SSIs not only provide basis for but also provide convenience for the development of STEM activities due to some features. The features that PSTs mentioned are grouped under 3 categories and are given in Table 3. 
Table 3. Features of SSIs that provide convenience for the development of STEM activities

\begin{tabular}{lc}
\hline Category & Frequency (f) \\
\hline Suitability to real life & 12 \\
Having more than one solution & 10 \\
Integration with other disciplines & 10 \\
\hline
\end{tabular}

PSTs indicated that SSIs provide convenience for the development of STEM activities as they are suitable to real life (f $=$ 12 ), as they have more than one solution due to their nature ( $f=10$ ) and as they can easily integrate with other STEM disciplines besides science. Some of the PSTs expressed their opinions as follows.

\section{"... I know that suitability to real life is important for STEM activities. Socio-scientific issues are scientific topics} from our lives. For this reason, it was easy to plan the activity... " (PST7)

“... Contexts that are suitable to real life was important. Socio-scientific issues made it possible. And, there is not a single solution to the problems in life. STEM activities should be similar and should make students think. Socioscientific issues already require multidimensional thinking... (PST9)

“...Socio-scientific issues require science knowledge. But for example, we discussed the GMOs issue in our activity, and this is not just science. We also need, for example, to think about the need for food, for how long and how much is needed to meet the needs, and so on. It does not make sense just to say -I am against GMOs-. We need other disciplines to see multilaterally, so the interrelationship is automatically established..." (PST12)

PSTs were given systematic feedback as they planned their STEM activities and during these feedback dialogues, it was observed that due to the fact that SSIs are naturally from our lives, structuring a problem situation around them is easy. These feedbacks were recorded by the researchers as field notes. PSTs were able to integrate mathematics more easily than other disciplines in their activity plans. In some SSIs (like nuclear power and GMOs), however, it was found that engineering was easier to work with.

Each STEM activity plan that PSTs developed (GMOs, nuclear power, cloning, hydro-electric power) was studied in the class. In this process, PSTs participated in the activities of each group as students. All of the PSTs (f $=12$ ) mentioned that they found the activities suitable for STEM education. Their evaluations of the activities are given in Table 4.

Tablo 4. PSTs evaluations of the activity plans based on SSIS

\begin{tabular}{|c|c|c|}
\hline Category & Code & Frequency \\
\hline \multirow{5}{*}{ 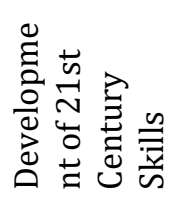 } & Decision making & 11 \\
\hline & Reasoning & 10 \\
\hline & Critical Thinking & 10 \\
\hline & Problem solving & 10 \\
\hline & Ethical Reasoning & 9 \\
\hline \multirow[b]{2}{*}{ 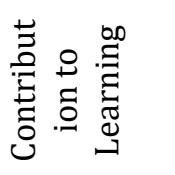 } & Interesting & 12 \\
\hline & Suitability to daily life & 12 \\
\hline
\end{tabular}

PSTs evaluated the activities as contributing to the development of 21 st century skills. Decision making ( $\mathrm{f}=11$ ), critical thinking $(\mathrm{f}=10)$, reasoning $(\mathrm{f}=10)$, problem solving $(\mathrm{f}=10)$, and ethical reasoning $(\mathrm{f}=9)$ were the skills they mentioned.

Some sample views are as follows:

"While reading resources about STEM education and in the activities we have done before, the most important thing was to contribute to the necessary skills required in the 21st century. I think the socioscientific issues in these interdisciplinary activities develop the ability of decision making. In making a decision, it also allows us to make comments and inquiries from the ethical point of view, either positive or negative." (PST3)

"The initiative problem situation for STEM education in the activities was indeed in real life. For example, the nuclear issue was exactly a problem in the environment we live in. We realized that we were trying to solve the problem while trying to find solutions with different disciplines..." (PST7)

As can be seen from the statements, the PSTs believed that the STEM activities they constructed on SSIs contributed to the development of the 21st century skills. They also rated activities as contributing to learning by indicating that they were interesting $(\mathrm{f}=12)$ and suitable to daily life $(\mathrm{f}=12)$. Some sample views are as follows:

\footnotetext{
“...I think, these activities are interesting. For this reason, we did not get bored while dealing with the problem in detail..." (PST5)
} 
"The best thing about these activities is that, they are from everyday life. We are curious about the issues since they concern us, and on the other hand we learn about them, as well..."(PST8)

"That makes it interesting that, the topics are from the real life and other disciplines like mathematics and engineering are involved in the work." (PST1)

Findings from field notes showed that PSTs participated in the activities actively. In deed, it was observed that some PSTs (i.e., PST4 and PST9) who usually showed less participation to the courses, actively participated in all activities. This situation appeared in the field notes as follows:

"PST4 and PST9 were two less active students that I know from the courses I have previously taught. During these activities, they surprisingly worked actively and posed a sharing and leader position in their own groups."

While strolling among the groups, it was observed that the PSTs made group discussions among themselves. It was also found that the PSTs tried to address the positive or negative ideas they held and reflect their inquiry processes in their discussions. It can be argued that the implementation processes developed the tasks of reasoning, decision making and problem solving. The findings obtained from the field notes support their evaluations of SSI based STEM activities, as well.

\section{Discussion and Conclusion}

Participants of this study, who attended to theoretical and practical courses on STEM education and developed, implemented and participated in the STEM activities where SSIs are used as problem situations, rated the use of SSIs in STEM education as suitable since they are suitable to real life, have more than one solution due to their nature and can easily integrate with other STEM disciplines besides science. Moreover, it was observed that the activity plans developed by the PSTs were suitable both for the teaching of the SSIs and the realization of the STEM education. Two of the activity plans developed by the PSTs integrated science, mathematics and engineering disciplines, while three integrated science and mathematics. The problem situations presented in the activity plans were constructed in a structure that suits the socio-cultural context of the students and provided multiple solutions.

PSTs had knowledge about the theoretical background of STEM education. They also participated in sample applications. The PSTs had the theoretical knowledge about the SSIs, as well. However, they did not previously practice STEM activities in the context of the socio-scientific problem situations. Their existing background was possibly effective in planning and implementing STEM activities based on SSIs. And, it was observed that the lesson plans they developed were appropriate for the nature of STEM education. Indeed, when the studies dealing with the characteristics of the SSIs are examined (Eastwood et al., 2012; Fleming, 1986; Topcu, 2010; Zeidler, Walker, Ackett \& Simmons, 2002; Zeidler, 2001), it is thought that they can provide contexts suitable for realizing STEM education.

During the study context of this study, PSTs found the opportunity to realize the activities they prepared in the classroom. They thought that the activities had the ability to develop many skills like decision making, reasoning, critical thinking, problem solving and ethical reasoning. They also considered the activities as motivating because they were interesting and were related to everyday life. Due to their nature, SSIs, require the decision-making skills to be employed (Bell \& Lederman, 2003). Similarly, the need for multiple solutions to the problem situations in STEM activities and the need for choosing the best solution suggests that decision making skills are widely used in these activities (Fila \& Purzer, 2013; Purzer, Moore, Baker \& Berland, 2014). In socio-scientific decision-making processes, it is frequently emphasized to consider sustainable development, and to understand the risks that interact with values, the benefit-cost analyzes and the values and moral judgments (Ratcliff \& Grace, 2003). Khan (2015) points out the importance of ethics in STEM education. The PSTs were in agreement with the literature that the activities they planned developed ethical reasoning. This finding also indicates that the PSTs could evaluate structuring STEM activities on the basis of SSIs in an appropriate manner with the related literature.

Zeidler (2016) emphasizes the importance of structuring STEM education in accordance with the socio-cultural context, and taking this understanding into account from the framework of the reasoning of SSIs. The fact that PSTs indicated skills like critical thinking, reasoning and decision-making, demonstrates that this finding is compatible with the expectations in the literature about SSIs as STEM contexts. The related literature and the findings obtained from the PSTs in this study indicate that SSIs provide basis for the realization of integrated teaching. Indeed, the fact that in their activity plans the PSTs integrated science with other disciplines and the activities included multi-criteria decision making processes, is a remarkable indicator that the SSIs will create appropriate contexts for STEM education (Khan, 2015; Zeidler, 2016; Zouda, et al. 2017).

In conclusion, it can be said that socio-scientific problem situations can be used to perform STEM activities. In this study, PSTs planned problem-based STEM activities where they took socio-scientific issues as problem situations. In this research, the skills that are thought to be developed through the related activities were revealed in terms of the opinions of the PSTs. It may be advisable for researchers to plan SSI based STEM activities for the students at different grade levels and to investigate the skills they will develop. 


\section{References}

Asghar, A., Ellington, R. , Rice, E. , Johnson, F., \& Prime, G. M. (2012). Supporting STEM education in secondary science contexts. Interdisciplinary Journal of Problem-Based Learning, 6(2), 85-125.

American Association of Colleges and Universities [AACU], (2007). College learning for the new global century. Washington, DC: AACU. Retrieved from https://www.aacu.org/sites/default/files/files/LEAP/GlobalCentury final.pdf.

Bell, R. L., \& Lederman, N. G. (2003). Understanding of the nature of science and decision making on science and technology based issues. Science Education, 87, 352-377.

Bozkurt Altan, E. (2017). Fen, teknoloji, muhendislik ve matematik (FeTeMM-STEM) egitimi [Science, technology, engineering and mathematic (STEM) education]. Hasturk, H. G. (Ed.) Teoriden pratige fen bilimleri ogretimi [The science education from theoretical to practical. Ankara: Pegem Press.

Bowers, S. W. (2015). Supporting elementary education in-service teachers' proficiency in planning STEM Centric lessons (Unpublished Doctoral Dissertation). Virginia Polytechnic Institute, Virginia.

Breiner, J. M., Harkness, S. S., Johnson, C. C., \& Koehler, C. M. (2012). What is STEM? A discussion about conceptions of stem in education and partnerships. School Science and Mathematics, 112, 1(2012), 3-11.

Bybee, R. (2010). Advancing STEM education: a 2020 vision. Technology and Engineering Teacher, 70(1), 30-35.

Chen, P. H. (2007). A study of STEM integrated teaching applied in the field of physics in junior high school (Unpublished master thesis). National Pingtung University of Science and Technology, Pingtung,

Chiu, A., Price, C. A., \& Ovrahim, E. (2015). Supporting elementary and middle school STEM education at the whole school level: a review of the literature. NARST 2015 Annual Conference. Chicago, IL. Paper retrieved from https://www.msichicago.org/fileadmin/assets/educators/science_leadership_initiative/SLI_Lit_Review.pdf

Driver, R., Newton, P., \& Osborne, J. (2000). Establishing the norms of scientific argumentation in classrooms. Science Education, 84, 287-312.

Eastwood, J., Sadler, T., Zeidler, D., Lewis, A., Amiri, L., \& Applebaum, S. (2012). Contextualizing nature of science instruction in socioscientific issues. International journal of Science Education, 34(15), 2289-2315.

Ercan, S. (2016). Improving prospective science teachers' integrated stem teaching competencies. International Conference on Education in Mathematics, Science \& Technology (ICEMST) 2016. Bodrum / Turkey. Paper retrieved from https://www.2016.icemst.com/ICEMST2016_Proceeding_Book.pdf?rnd=2049620557

Fila, N. D. \& Purzer, S. (2013, June). The quality of engineering decision-making in student design teams. 120 th ASEE Annual Conference \& Exposition. Atlanta, USA. Paper retrieved from https://www.asee.org/public/conferences/20/papers/7008/view

Fleming, R. (1986). Adolescent reasoning in socio-scientific issues. Part I: Social cognition. Journal of Research in Science Teaching, 23, 677-687.

Harrel, P. E. (2010). Teaching an integrated science curriculum: Linking teacher knowledge and teaching assignments. Issues in Teacher Education, 19(1), 145-165.

Hmelo, C. E., Holton, D., \& Kolodner, J. L. (2000). Designing to learn about complex systems. The Journal of the Learning Sciences, 9(3), 247-298.

International Society for Technology in Education [ISTE]. (2007). The national educational technology standards and performance indicators for students. Eugene, OR: ISTE.

Khan, S. (2015). Another "M" for STEM? moral considerations for advancing STEM literacy. K-12 STEM Education, 1(4), 149-156.

Kolstø, S.D. (2001). Scientific literacy for citizenship: Tools for dealing with the science dimension of controversial socioscientific issues. Science Education, 85, 291-310.

Lou, S. J., Shih, E. C., Diez, C. R., \& Tseng, K. H. (2011). The impact of problem-based learning strategies on STEM knowledge integration and attitudes: an exploratory study among female Taiwanese senior high school students. International Journal of Technology and Design Education, 21(2), 195-215.

Mehalik, M., Doppelt, Y., \& Schunn, C. D. (2008). Middle school science through design based learning versus scripted inquiry: better overall science concept learning and equity gap reduction. Journal of Engineering Education, January, 97(1), 71-85. 
Marshall, C., \& Rossman, G. B. (2006). Designing qualitative research (4th Edition). USA: Sage Publications.

Miles, M. B., \& Huberman, A. M. (1994). Qualitative data analysis. London: Sage Publication.

Moore, T.J., Stohlmann, M.S., Wang, H.-H., Tank, K.M., \& Roehrig, G.H. (2014). Implementation and integration of engineering in K-12 STEM education. J. Strobel, S. Purzer, \& M. Cardella (Ed.), Engineering in precollege settings: Research into practice. Rotterdam, the Netherlands: Sense Publishers.

National Academy of Engineering [NAE] \& National Research Council [NRC] (2009). Engineering in K-12 education understanding the status and improving the prospects. Edt. Katehi, L., Pearson, G. \& Feder, M. Washington, DC: National Academies Press.

National Research Council [NRC]. (2012). A Framework for $k$-12 science education: practices, crosscutting concepts, and core ideas. Washington DC: The National Academic Press.

Partnership for 21st Century Skills [P21], (2013). A Report and mile guide for 21th century skills. Washington DC: Partnership for 21st Century Skills.

Purzer, S., Moore, T. J., Baker, D. \& Berland, L. (2014, April). Supporting the implementation of NGSS through research: engineering. NARST Annual International Conference. Pittsburgh, USA. Paper retrieved from https://narst.org/ngsspapers/Engineering_June2014.pdf

Ratcliffe, M., \& Grace, M. (2003). Science education for citizenship. teaching socio-scientific issues. Maidenhead: Open University Press.

Sanders, M. (2009). STEM, STEM education, STEMmania. The Technology Teacher, 68(4), 20-26.

Sadler, P. M., Coyle, H. P., \& Schwartz, M. (2000). Engineering competitions in the middle school classroom: Key elements in developing effective design challenges. The Journal of the Learning Sciences, 9, 299-327.

Stearns, L. M., Morgan, J., Capraro, M. M., \& Capraro, R. M. (2012). A teacher observation instrument for PBL classroom instruction. Journal of STEM Education: Innovations and Research, 13(3), 7

Stohlmann, M., Moore, T. J. \& Roehrig, G. H. (2012). Considerations for teaching integrated STEM education. Journal of Pre-College Engineering Education Research (J-PEER), 2(1), Article 4. Retrieved from http://dx.doi.org/10.5703/1288284314653.

Strauss, A., \& Corbin, J. (1994). Grounded theory methodology: An overview. In N. K. Denzin \& Y.S. Lincoln (Eds.), Handbook of qualitative research (p. 273-285). London: Sage Publications.

Topcu, M. S. (2010). Development of attitudes towards socioscientific issues scale for undergraduate students. Evaluation and Research in Education, 23(1), 51-67.

Tsai, H. W. (2007). A study of STEM instructional model applied to science and technology in junior high school. (Unpublished doctoral dissertation). National Pingtung University of Science and Technology, Pingtung, Taiwan.

Yin R. K. (2009). Case study research: Design and methods (4th ed.). California: SAGE Pub. Thousand Oaks.

Zeidler, D. L., Walker, K. A., Ackett, W. A., \& Simmons, M. L. (2002). Tangled up in views: Beliefs in the nature of science and responses to socioscientific dilemmas. Science Education, 86, 343-367.

Zeidler, D.L. (1984). Moral issues and social policy in science education: Closing the literacy gap. Science Education, 68, 411-419.

Zeidler, D. L. (2001). Standard F: Participating in program development. In E. Siebert \& W. Mcintosh (Eds.), Pathways to the science standards: College edition (pp. 18-22). Arlington: VA National Science Teachers Association.

Zeidler, D. L. (2016). STEM education: A deficit framework for the twenty first century? A sociocultural socioscientific response. Cult Stud of Sci Educ., 11, 11-26

Zouda, M. El Halwany, S., Milanovic, M., \& Bencze, L. (2017). Addressing socioscientific issues through STEM education: The case of STEM coaches. Europen Science Education Research Association (ESERA) Conference. Dublin City University. Dublin, Ireland, 21 st-25 th August. Retrieved from https://keynote.conferenceservices.net/resources/444/5233/pdf/ESERA2017_0491_paper.pdf 